\title{
Insecticidal and genotoxic activity of Psoralea corylifolia Linn. (Fabaceae) against Culex quinquefasciatus Say, 1823
}

Virendra K Dua' ${ }^{1 *}$, Arvind Kumar ${ }^{2}$, Akhilesh C Pandey ${ }^{1}$ and Sandeep Kumar ${ }^{1}$

\begin{abstract}
Background: Indiscriminate use of synthetic insecticides to eradicate mosquitoes has caused physiological resistance. Plants provide a reservoir of biochemical compounds; among these compounds some have inhibitory effect on mosquitoes. In the present study the larvicidal, adulticidal and genotoxic activity of essential oil of Psoralea corylifolia Linn. against Culex quinquefasciatus Say was explored.

Methods: Essential oil was isolated from the seeds of P. corylifolia Linn. Larvicidal and adulticidal bioassay of CX. quinquefasciatus was carried out by WHO method. Genotoxic activity of samples was determined by comet assay. Identification of different compounds was carried out by gas chromatography- mass spectrometry analysis.

Results: $L C_{50}$ and $L C_{90}$ values of essential oil were $63.38 \pm 6.30$ and $99.02 \pm 16.63$ ppm, respectively against CX. quinquefasciatus larvae. The $L D_{50}$ and $L D_{90}$ values were $0.057 \pm 0.007$ and $0.109 \pm 0.014 \mathrm{mg} / \mathrm{cm}^{2}$ respectively against adult Cx. quinquefasciatus, Genotoxicity of adults was determined at 0.034 and $0.069 \mathrm{mg} / \mathrm{cm}^{2}$. The mean comet tail length was $6.2548 \pm 0.754 \mu \mathrm{m}$ and $8.47 \pm 0.931 \mu \mathrm{m}$ and the respective DNA damage was significant i.e. $6.713 \%$ and $8.864 \%$ in comparison to controls. GCMS analysis of essential oil revealed 20 compounds. The major eight compounds were caryophyllene oxide (40.79\%), phenol,4-(3,7-dimethyl-3-ethenylocta-1,6-dienyl) (20.78\%), caryophyllene (17.84\%), a-humulene (2.15\%), (+)- aromadendrene (1.57\%), naphthalene, 1,2,3,4-tetra hydro-1,6dimethyle-4-(1-methyl)-, (1S-cis) (1.53\%), trans- caryophyllene (0.75\%), and methyl hexadecanoate (0.67\%).

Conclusion: Essential oil obtained from the seeds of $P$. corylifolia showed potent toxicity against larvae and adult $C x$. quinquefasciatus. The present work revealed that the essential oil of $P$. corylifolia could be used as environmentally sound larvicidal and adulticidal agent for mosquito control.
\end{abstract}

Keywords: Larvicidal activity, Adulticidal activity, Genotoxicity, DNA damage, Essential oil, Psoralea corylifolia, Culex quinquefasciatus, GCMS

\section{Background}

Mosquitoes are an important public health concern around the world. They not only cause nuisance to humans but also transmit several diseases like malaria, filaria, Japanese encephalitis, dengue fever, chikungunya [1] and yellow fever [2]. These diseases affect the health and quality of life of millions of people in subtropical and tropical countries [3]. Mosquitoes also cause allergic responses in humans that include local skin and

\footnotetext{
*Correspondence: vkdua51@gmail.com

${ }^{1}$ National Institute of Malaria Research, Sector-3, Health Centre, Field Unit BHEL, Ranipur, Hardwar, Uttrakhand 249403, India

Full list of author information is available at the end of the article
}

systemic reactions such as angioedema [4]. In 2010, The WHO reported 216 million cases of malaria in the world with an estimated 6,55,000 malaria deaths [5]. An estimated 120 million people in tropical and subtropical areas of the world are infected with lymphatic filariasis [6]. Three billion people in the endemic areas are at risk of infection with Japanese encephalitis and incidence of the disease is $30,000-50,000$ cases annually [7]. Over $40 \%$ of the world's population (approximately 2.5 billion) is at risk from dengue, WHO estimated $50-100$ million dengue infections worldwide, annually [8]. Moreover, there are an estimated 200,000 cases of yellow fever (causing 30,000 deaths) worldwide annually [9]. Culex 
quinquefasciatus Say, 1823 (widely distributed mosquito in India) is a vector of important diseases, such as West Nile virus, filariasis, Japanese encephalitis, St. Louis encephalitis, avian malaria and bancroftian filariasis (Wuchereria bancrofti) [10]. Cx. quinquefasciatus is responsible for major public health problems in India with around 31 million microfilaraemics, 23 million cases of symptomatic filariasis, and about 473 million individuals potentially at risk of infection [11].

Synthetic insecticides were used extensively during the 1950 s to control malaria in various countries by indoor residual spraying (IRS) as a larvicide [12]. Synthetic insecticides were also used to control adult mosquitoes by fogging [13]. The continuous use of synthetic insecticide such as malathion, DDT, $\mathrm{HCH}$ and deltamethrin for controlling mosquitoes has created diverse environmental problems such as toxicity to non target organisms [14], development of genetic resistance in mosquitoes [15], environment pollution [16] and their non degradable nature results in biomagnifications. Herein, the worldwide continuous efforts to eradicate and control this vector were found ineffective. Therefore, there is a need to search for environmentally safe, degradable and target specific insecticides. Plant derived essential oils are emerging as a potential source for mosquito control agents, since they constitute a rich source of bioactive compounds that are biodegradable and potentially suitable for controlling mosquitoes. Earlier researchers have reported the efficacy of several plant essential oils against mosquito larvae [17-21] and adults [22-26].

Psoralea corylifolia Linn. is an erect, herbaceous, and annual weed growing up to a height of $60-120 \mathrm{~cm}$ in the plains of central and eastern India, China, and in some parts of Arabia under semi arid conditions [27]. Seeds are usually brownish-black in color, smooth, and adhere to the pericarp $[28,29]$. The plant is widely used in several skin diseases such as psoriasis [30], leucoderma and leprosy [31]. The therapeutic action of $P$. corylifolia against various diseases such as asthama, diarrhoea, alopecia areata [32], impotency, menstruation disorder and uterine hemorrhage [33]. Moreover it has antitumor [34], antiallergic [35], antioxidant [36], insecticidal [37] and antimicrobial activity [38]. The plant has also been used for the treatment of enuresis, various kidney problems [39], depression [40], osteoporosis and bone fractures [27]. In the present study the larvicidal, adulticidal and genotoxic activity of volatile oil extracted from seeds of $P$. corylifolia against $C x$. quinquefasciatus and the phytochemical analysis of volatile oil by GC-MS was determined.

The single cell gel electrophoresis (SCGE or Comet assay) is one of the most promising and imminent genotoxicity tests. It is less resource intensive than the usual genotoxic techniques and permits both qualitative and quantitative assessment of DNA damage in individual eukaryotic cells. The sensitivity of the SCGE technique has been applied in many areas, e.g. environmental monitoring [41], in vivo and in vitro genotoxicity testing [42] and epidemiological and biomonitoring studies in human populations exposed occupationally, environmentally or clinically $[43,44]$. This test procedure has been recommended in the Committee on Mutagenicity Guidelines of the UK Department of Health (COM) for determining in vitro mutagenicity of chemicals [45].

\section{Methods}

Plant material

Plants with seeds of $P$. corylifolia (Fabaceae) collected from Garhwal region of Himalaya were purchased from the Arya Vastu Bhandar Dehradun, Uttarakhand, India, which were further confirmed by Botanical Survey of India (BSI), Dehradun, India. The Voucher specimen of the whole plant and its seeds were kept in the Institute herbarium for future reference (Voucher Specimen No: NIMRHAR-101PC-1).

\section{Isolation of the essential oils}

The collected seeds of $P$. corylifolia were washed with distilled water and dried under shade. The dried seeds $(100 \mathrm{~g})$ were powdered with the help of a grinder and mixed in water (1:6); further steam distillation (in a Clevenger apparatus for $7 \mathrm{~h}$ ), extracted the essential oil. The oil layer was separated from the aqueous phase using nhexane with the help of a separating funnel. The volatile essential oil was dried using anhydrous sodium sulfate, and stored at $4^{\circ} \mathrm{C}$ until used.

\section{GC-MS analysis}

The GC-MS analysis was carried out on a Shimadzu (QP 2010) series GC-MS (Tokyo, Japan) system equipped with AOC-20i auto-sampler and coupled with DB-5 MS capillary column (Agilent technologies, made in USA), (30 m $\times 0.25 \mathrm{~mm}$ i.d., $0.25 \mu \mathrm{m})$. Helium was used as carrier gas at a flow rate of $1.28 \mathrm{ml} / \mathrm{min}$; split ratio of 1: 50; mass scan 50-800; ionization energy, 70 $\mathrm{eV}$; ion source temperature, $200^{\circ} \mathrm{C}$; injector temperature, $250^{\circ} \mathrm{C}$. Oven temperature was programmed as follows: initially at $40^{\circ} \mathrm{C}$ for $5 \mathrm{~min}$, rising at $4^{\circ} \mathrm{C} / \mathrm{min}$ to $220^{\circ} \mathrm{C}$ and then held isothermally $(5 \mathrm{~min})$ at $220^{\circ} \mathrm{C}$. The oil sample $(10 \mu \mathrm{l})$ was diluted (up to $2 \mathrm{ml}$ ) with dichloromethane (HPLC grade), sample injection volume was $1 \mu \mathrm{l}$. Individual components were identified by comparison of their mass spectra (MS) with NIST database and Adams libraries from the derived fragmentation pattern [46,47]. 


\section{Test organisms}

The test organism Cx. quinquefasciatus Say, 1823, was reared continuously from several generations in the Entomology Laboratory of the National Institute of Malaria Research, Field Unit, Hardwar, India. They were free of exposure to pathogens and insecticides and maintained at $26 \pm 2{ }^{\circ} \mathrm{C}$ and $60-80 \%$ relative humidity. The larvae were fed on dog biscuits and yeast powder in a ratio 3:2 until moulting to become pupae, pupae were transferred into a mosquito cage. The emergent adults were fed with $10 \%$ glucose solution dipped in a piece of cotton in humidified cages.

\section{Larvicidal bioassay}

Larvicidal activities of the essential oil of $P$. corylifolia were determined in terms of $\mathrm{LC}_{50}$ and $\mathrm{LC}_{90}$ by using the standard procedure of WHO [48] with slight modification. Twenty early fourth instar larvae of $C x$. quinquefasciatus, were transferred to $500 \mathrm{ml}$ bowls containing 249 $\mathrm{ml}$ of dechlorinated tap water. The essential oil was dissolved in $1 \mathrm{ml}$ acetone to prepare a serial dilution of test dosage and mixed in $249 \mathrm{ml}$ tap water containing 20 early fourth instar larvae. Three replicates were run simultaneously with at least six dosages 25-100 $\mu \mathrm{g} / \mathrm{ml}$ (ppm) along with control (1 $\mathrm{ml}$ of acetone alone to 249 $\mathrm{ml}$ of tap water). Bioassay was conducted at room temperature $26 \pm 2{ }^{\circ} \mathrm{C}$ with $60-80 \%$ relative humidity, during which time no food was offered to the larvae. Mortality of larvae was recorded $24 \mathrm{~h}$ post treatment and evaluated $\mathrm{LC}_{50}$ and $\mathrm{LC}_{90}$ by using probit analysis and StatusPlus2009 software.

\section{Adulticidal bioassay}

Adulticidal bioassay was performed according to WHO guidelines [49] against Cx. quinquefasciatus and lethal dose $\left(\mathrm{LD}_{50}\right.$ and $\left.\mathrm{LD}_{90}\right)$ and knockdown time $\left(\mathrm{KDT}_{50}\right.$ and $\mathrm{KDT}_{90}$ ) were evaluated. Different concentrations ranges of the essential oil of $P$. corylifolia were prepared in 2.5 $\mathrm{ml}$ of acetone and homogenously applied on Whatman no. 1 filter papers (size $12 \times 15 \mathrm{~cm}^{2}$ ), control papers were treated with $2.5 \mathrm{ml}$ of acetone under similar conditions and placed in WHO exposure tubes. 20 adult mosquitoes (2-5 days old glucose fed mosquitoes) were exposed on treated paper for one hour and knocked down and live mosquitoes were counted at 5 minute intervals. After one-hour exposure mosquitoes was transferred into WHO holding test tubes for a 24 hour recovery period. During this period the mosquitoes were kept at room temperature at $26 \pm 2^{\circ} \mathrm{C}$ and $70-80 \%$ relative humidity. The mortality was observed after 24 hours [50]. Three replicates were run simultaneously with at least six doses $(0.034,0.055,0.069,0.104,0.138$ and $0.173 \mathrm{mg} / \mathrm{cm}^{2}$ ) to produce a range of mortality from 15 to $100 \%$ along with controls. Lethal dose $\left(\mathrm{LD}_{50}\right.$ and
$\left.\mathrm{LD}_{90}\right)$ and knocked down time $\left(\mathrm{KDT}_{50}\right.$ and $\left.\mathrm{KDT}_{90}\right)$ were calculated by probit analysis using StatusPlus2009 software.

\section{Positive control}

Advance studies on adulticidal activity was carried out by using $0.05 \%$ deltamethrin (DM) impregnated paper as a positive control against female $C x$. quinquefasciatus for determination of $\mathrm{KDT}_{50}$ and $\mathrm{KDT}_{90}$ value.

\section{Genotoxicity testing by comet assay}

The DNA damage studies were carried out using Single Cell Gel Electrophoresis (SCGE), commonly known as comet assay. The protocol (Alkali method) was followed as described by Singh et al. [51] with minor modifications as described below.

\section{Slide preparation}

Twenty mosquitoes were exposed to $0.034 \mathrm{mg} / \mathrm{cm}^{2}$ and $0.069 \mathrm{mg} / \mathrm{cm}^{2}$ concentrations of the essential oil of $P$. corylifolia as well as controls, for $1 \mathrm{~h}$ in WHO exposure tubes and were homogenized in $10 \%(\mathrm{w} / \mathrm{v})$ homogenizing buffer $(0.075 \mathrm{M} \mathrm{NaCl}$ and $0.024 \mathrm{M}$ EDTA). Homogenate was centrifuged at $1000 \mathrm{rpm}$ for $10 \mathrm{~min}-$ utes and the pellet was gently resuspended in $1 \mathrm{ml}$ of chilled homogenizing buffer for nuclei preparation. Frozen microscopic slides were then placed horizontally and a homogenous thin layer of $1 \%$ normal melting agarose was cast onto the slide, isolated nuclei and $1 \%$ low melting agarose [(1:4), $100 \mu \mathrm{l}]$ were mixed and cast onto the precoated slides and kept at $4^{\circ} \mathrm{C}$ for 20 minute. The slides were immersed into the freshly prepared chilled lysis buffer (2.5 M NaCl, $100 \mathrm{mM}$ EDTA pH 10, 5\% DMSO, $1 \%$ and Triton-X 100) for 1 hour in the dark at $4^{\circ} \mathrm{C}$. After complete lysis the slides were placed for $20 \mathrm{~min}$ in an ice cold electrophoresis chamber containing alkaline electrophoresis buffer (1mM EDTA and 300 $\mathrm{mM} \mathrm{NaOH}, \mathrm{pH}>13$ ) to facilitate unwinding of DNA strands, the process was subsequently conducted for 20 minutes at 25 volts $/ 300 \mathrm{~mA}$. The slides were washed thrice with neutralizing buffer $(0.4 \mathrm{M}$ Tris $\mathrm{pH}$ 7.5) for 5 minutes and just before visualization. Slides were then stained with ethidium bromide $(20 \mu \mathrm{g} / \mathrm{ml}, 40 \mu \mathrm{l} /$ slide $)$ for $10 \mathrm{~min}$ in the dark. Slides were then dipped once in chilled distilled water to remove excess ethidium bromide and subsequently cover slips were placed over them. The slides were stored in a dark, humidified chamber and analyzed within $3 \pm 4 \mathrm{~h}$.

\section{Comet capture and analysis}

A total of 100 cells from each slide were analyzed by image analysis using a fluorescence microscope (Leica DM4000B) with an excitation filter of 515-560 nm and a barrier filter of $590 \mathrm{~nm}$ using X10 objectives. The 
photographs of the individual cells were taken using a Leica Digital DFC 320R-II camera. Comet tail length and percentage of DNA damage in tail were measured with an Image Analysis System (Leica Qwin) and Comet Score software version 1.5 (TriTek Corporation, Sumerduck, VA).

\section{Statistical analysis}

Statistical analysis of the experimental data was performed using the computer software StatPlus ${ }^{\circledR} 2009$ (AnalystSoft, Canada) to find the lethal concentration/ dose against larvae $\left(\mathrm{LC}_{50}\right.$ and $\left.\mathrm{LC}_{90}\right)$ and adult $\left(\mathrm{LD}_{50}\right.$ and $\mathrm{LD}_{90}$ ) in $24 \mathrm{~h}$ and also determines the knockdown time $\left(\mathrm{KDT}_{50}\right.$ and $\left.\mathrm{KDT}_{90}\right)$ by probit analysis [52] with a reliability interval of $95 \%$. To determine whether there was a statistically significant difference among different doses of $P$. corylifolia essential oils against mosquito larvae and adults, Student's t-test was used to analyze the difference of the percentage of mortality. Results with $\mathrm{P}<$ 0.05 were considered to be statistically significant.

The corrected percent mortality was evaluated by using Abbott's formula-

$$
\text { Corrected Mortality }(\%)=\frac{[\mathrm{MT}-\mathrm{MC}]}{100-\mathrm{MC}} \times 100
$$

where MT and MC are percent mortality in treated and control experiment, respectively [53].

\section{Results and discussion}

The average yield of essential oil was $2 \% \mathrm{w} / \mathrm{w}$ according to their dry weight. Oil is a complex mixture of several compounds; chemical constituents of analyzed oils are displayed in Table 1.

\section{Phytochemical screening}

A total of 20 compounds were identified in seeds of $P$. corylifolia essential oil. Compounds occurring in trace amounts are not reported in this article. Caryophyllene derivatives (caryophyllene oxide and caryophyllene) are major fractions of the essential oil (59.30\%), among the caryophyllene derivatives, caryophyllene oxide and caryophyllene contributed $2 / 3$ and $1 / 3$ fraction, respectively. But 8 major compounds constituting $86.08 \%$ of the $P$. corylifolia seed essential oil were caryophyllene oxide, phenol, 4-(3,7-dimethyl-3-ethenylocta-1,6-dienyl), caryophyllene, $\alpha$-Humulene, (+)- aromadendrene, naphthalene, 1,2,3,4-tetra hydro-1,6-dimethyle-4-(1-methyl)-, (1S-cis), trans- caryophyllene, and methyl hexadecanoate (Table 1). The results differ from Kapoor [54] and Sharma et al. [55] who reported that the main constituent of essential oil of $P$. corylifolia seeds have limonene, $\alpha$-elemene, $\gamma$-elemene, $\beta$-caryophylenoxide, 4-terpineol, linalool, geranylacetate. We assume that the discrepancy might have been caused by the differences in the chemo types of the species. Several studies have shown that caryophyllene oxide and caryophyllene present in the essential oils of different plants possess significant insecticidal activities against different species of mosquitoes [56-59]. A range of essential oils exhibited bioactive properties against the larvae of $C x$. quinquefasciatus [21,60-62].

\section{Larvicidal activity}

In the present study larvicidal activity of essential oil from $P$. corylifolia was evaluated at different concentrations (range: 25-100 ppm) on early fourth instar larvae of $C x$. quinquefasciatus and 8.0, 18.5, 45.0, 85.0, 91.63 and $100.0 \%$ mortality was recorded at $25,50,65,75,90$ and $100 \mathrm{ppm}$, respectively (Figure 1). The data were analyzed using Student's t-test in which p values $<0.05$

Table 1 Major identified compounds in the essential oil of $\boldsymbol{P}$. corylifolia seeds by GCMS

\begin{tabular}{|c|c|c|c|c|c|}
\hline $\begin{array}{l}\text { S. } \\
\text { No. }\end{array}$ & $\begin{array}{l}\text { Retention } \\
\text { time (min) }\end{array}$ & $\begin{array}{l}\text { Concentration } \\
(\%)\end{array}$ & Constituents & Mass fragmentation pattern & $\begin{array}{l}\text { Match with } \\
\text { library }\end{array}$ \\
\hline 1 & 30.500 & 17.84 & caryophyllene & $\begin{array}{l}{[M+] 204,189,175,161,147,133,120,105,93} \\
79,69,55,51\end{array}$ & NIST147.LIB \\
\hline 2 & 31.688 & 2.15 & a-humulene & {$[\mathrm{M}+] 204,147,121,107,93,80,67,53$} & WILEY7.LIB \\
\hline 3 & 33.782 & 1.57 & (+)- aromadendrene & $\begin{array}{l}{[\mathrm{M}+] 204,187,161,147,134,119,106,96,81,} \\
69,55,51\end{array}$ & WILEY7.LIB \\
\hline 4 & 33.842 & 1.53 & $\begin{array}{l}\text { naphthalene, 1,2,3,4-tetra hydro-1,6- } \\
\text { dimethyle-4-(1-methyl)-, (1S-cis) }\end{array}$ & {$[M+] 202,159,144,131,105,69$} & WILEY7.LIB \\
\hline 5 & 35898 & 40.79 & (-)-caryophyllene oxide & $\begin{array}{l}{[\mathrm{M}+] 173,164,149,135,123,107,96,79,69,55} \\
53\end{array}$ & WILEY7.LIB \\
\hline 6 & 40.466 & 0.75 & trans- caryophyllene & $\begin{array}{l}{[M+] 236,203,189,175,161,147,133,119,105} \\
91,79,69,55,51\end{array}$ & WILEY7.LIB \\
\hline 7 & 45.419 & 0.67 & methyl hexadecanoate & $\begin{array}{l}{[\mathrm{M}+] 270,239,227,199,185,171,161,143,129} \\
119,101,87,74,69,55\end{array}$ & WILEY7.LIB \\
\hline 8 & 52.073 & 20.78 & $\begin{array}{l}\text { phenol,4-(3,7-dimethyl-3-ethenylocta-1,6- } \\
\text { dienyl) }\end{array}$ & $\begin{array}{l}{[M+] 256,213,185,173,158,145,127,121,107} \\
93,83,69,55,53\end{array}$ & NIST147.LIB \\
\hline
\end{tabular}




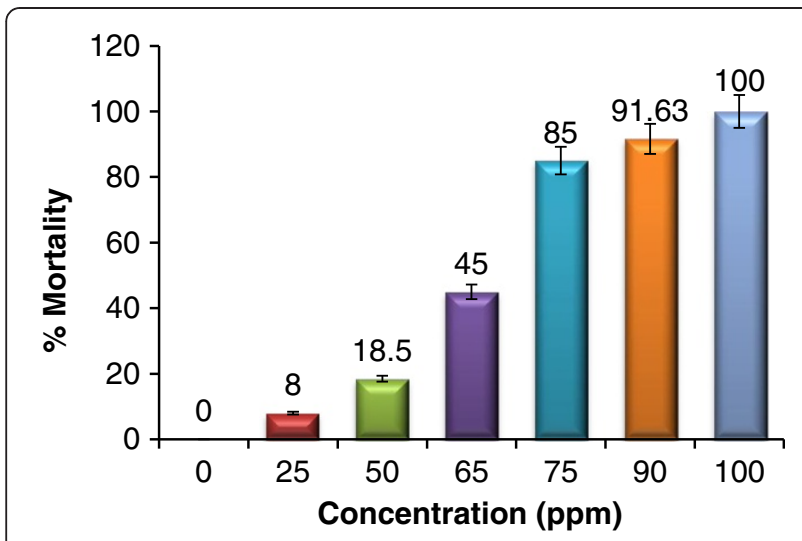

Figure 1 Mosquito larvicidal activities of seed essential oil from $P$. corylifolia against $C x$. quinquefasciatus larvae with significant concentration difference at $p<0.05$.

were taken to represent significant differences between mean values. Mean $\mathrm{LC}_{50}$ and $\mathrm{LC}_{90}( \pm$ standard error) values were $63.38 \pm 6.3 \mathrm{ppm}$ and $99.02 \pm 16.63 \mathrm{ppm}$ against Cx. quinquefasciatus larvae respectively (Table 2). In 2005, Dharmagadda and coworkers reported the larvicidal activity of Tagetes patula essential oil against the fourth instar larvae of Aedes aegypti, Anophleles stephensi, and $C x$. quinquefasciatus, the $\mathrm{LC}_{50}$ and $\mathrm{LC}_{90}$ values were 13.57, 12.08, 22.33 and 37.91, 57.62, 71.89 ppm respectively [62]. In 2009, Pavela screened 22 essential oils for their larvicidal activity, the essential oil obtained from Thymus vulgaris, Satureja hortensis and Thymus satureioides plants found potent larvicidal activity with $\mathrm{LC}_{50}$ of 33,36 and $44 \mathrm{~g} / \mathrm{ml}$, respectively against Cx. quinquefasciatus [60]. A series of plant essential oils were also reported as larvicide against different mosquito species $[57,63]$.

\section{Adulticidal activity}

A large number of plants are reported to have larvicidal activity, but very few of the plants are reported to have adulticidal activity $[22,24,50]$.

The present study demonstrates the adulticidal activity of essential oil from $P$. corylifolia at different concentrations $\left(0.034,0.055,0.069,0.104,0.138\right.$ and $\left.0.173 \mathrm{mg} / \mathrm{cm}^{2}\right)$ on Whatman no.1 impregnated filter paper, against female adult $C x$. quinquefasciatus mosquitoes and showed 16.66,

Table 2 Insecticidal activity of essential oil from seeds of $P$. corylifolia against $C x$. quinquefasciatus larvae and adults

\begin{tabular}{lccc}
\hline \multicolumn{2}{c}{ Larvicidal activity } & \multicolumn{2}{c}{ Adulticidal activity } \\
\hline LC $_{\mathbf{5 0}} \pm$ SE & LC $_{\mathbf{9 0}} \pm$ SE & LD $_{\mathbf{5 0}} \pm$ SE & LD $_{\mathbf{9 0}} \pm$ SE \\
\hline $63.38 \pm 6.3$ & $99.02 \pm 16.63$ & $0.057 \pm 0.007$ & $0.109 \pm 0.014$ \\
\hline
\end{tabular}

Six concentrations were tested with control (significantly different at $P<0.05$ ) three replicates were taken. ${ }^{\mathrm{SE}}$ Standard error, $\mathrm{LC}$ and $\mathrm{LD}$ values were determined by probit analysis.
45.00, 70.00, 85.00, 95.00 and 100\% mortality, respectively (Figure 2). The data were analyzed using Student's t-test in which $\mathrm{p}$ values $<0.05$ were taken to represent significant differences between mean values. The $\mathrm{LD}_{50}$ and $\mathrm{LD}_{90}$ values ( \pm standard error) were $0.057 \pm 0.007 \mathrm{mg} / \mathrm{cm}^{2}$ and $0.109 \pm 0.104 \mathrm{mg} / \mathrm{cm}^{2}$ against adult $C x$. quinquefasciatus respectively (Table 2); the results were compared with $0.05 \%$ deltamethrin (DM) impregnated paper. $\mathrm{KDT}_{50}$ and $\mathrm{KDT}_{90}$ values of the essential oil from $P$. corylifolia were $20.29 \pm 0.88,18.06 \pm 1.32,13.45 \pm 0.60,11.16 \pm 0.49,9.87 \pm 0.48$ $\min$ and $47.87 \pm 3.18,36.00 \pm 1.32,25.75 \pm 1.25,19.40 \pm 0.96$, $17.85 \pm 0.95 \mathrm{~min}$ respectively at $0.055,0.069,0.104,0.138$ and $0.173 \mathrm{mg} / \mathrm{cm}^{2}$ concentrations, respectively against $C x$. quinquefasciatus (Figure 3). $\mathrm{KDT}_{50}$ and $\mathrm{KDT}_{90}$ values of $0.05 \%$ deltamethrin impregnated papers were $14.91 \pm 0.67$ and $30.89 \pm 1.58 \mathrm{~min}$, respectively against Cx. quinquefasciatus, with $96.7 \%$ mortality (Table 3). Dua and collaborators (2008) [50] reported the adulticidal activity of essential oil of Valeriana jatamansi root against An. stephensi, An. culicifacies, Ae. aegypti, Ae albopictus, and $C x$. quinquefasciatus, with $\mathrm{LD}_{50}$ and $\mathrm{LD}_{90}$ values were $0.14,0.16,0.09,0.08,0.17 \mathrm{mg} / \mathrm{cm}^{2}$ and $0.24,0.34$, $0.25,0.21,0.28 \mathrm{mg} / \mathrm{cm}^{2}$, respectively; Whereas $\mathrm{KDT}_{50}$ and $\mathrm{KDT}_{90}$ values were $13,13,12,13,18 \mathrm{~min}$ and 24 , 25, 21, 20, 42 min against An. stephensi, An. culicifacies, Ae. aegypti, An. albopictus and $C x$. quinquefasciatus, respectively, using $0.28 \mathrm{mg} / \mathrm{cm}^{2}$ impregnated papers. In 2010 Dua et al. [22], reported the adulticidal activity of essential oil of leaves of Lantana camara against Ae. aegypti, Cx. quinquefasciatus, An. culicifacies, An. fluvialitis and $A n$. stephensi, $\mathrm{LD}_{50}$ values were $0.06,0.05$, $0.05,0.05$ and $0.06 \mathrm{mg} / \mathrm{cm}^{2}$ while $\mathrm{LD}_{90}$ values were 0.10 , $0.10,0.09,0.09$ and $0.10 \mathrm{mg} / \mathrm{cm}^{2}$ respectively. Whereas $\mathrm{KDT}_{50}$ values were $20,18,15,12,14 \mathrm{~min}$ and $\mathrm{KDT}_{90}$ values were $35,28,25,18$, and 23 min against Ae. aegypti,

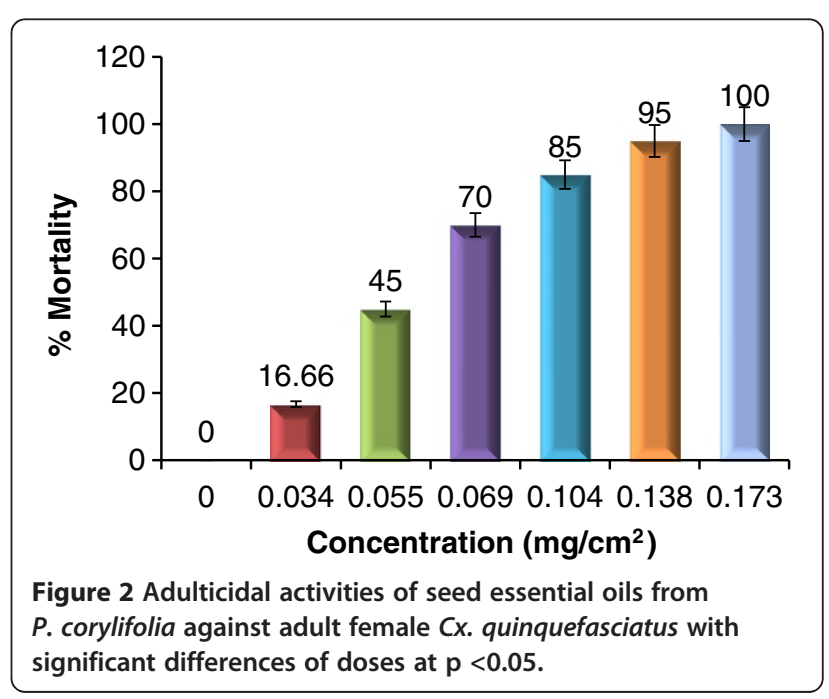




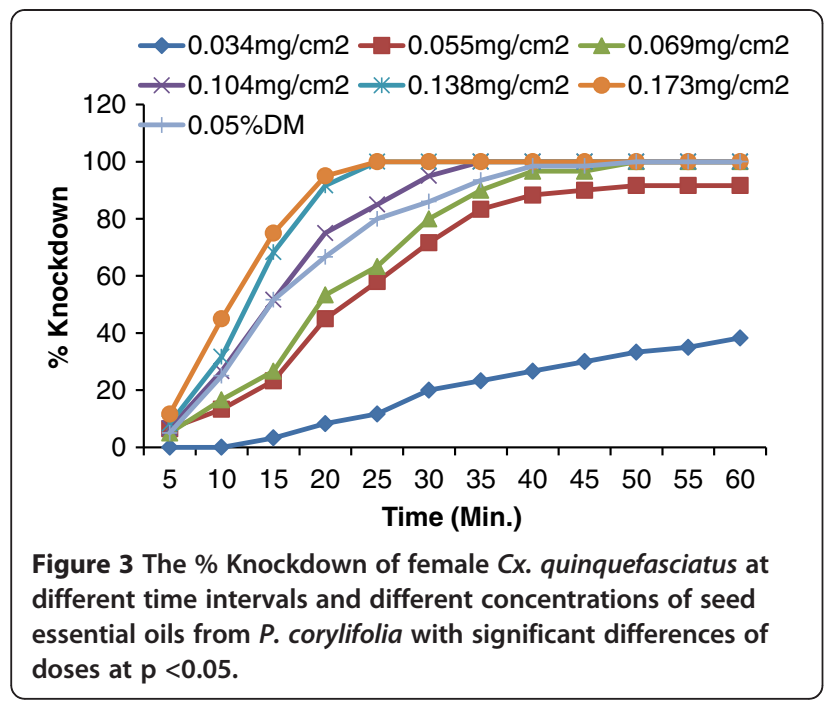

Cx. quinquefasciatus, An. culicifacies, An. fluviatilis and An. stephensi, respectively on $0.208 \mathrm{mg} / \mathrm{cm}^{2}$ impregnated paper. Adulticidal activity of five essential oils (Citrus sinensis, Mentha pipreta, Carvocryl oil, Citronela oil and citral oil) at different concentrations and time intervals was determined by Yang et al. (2005), the Rutaceae oil (C. sinensis) was found as the most toxic against $C x$. quinquefasciatus with $\mathrm{LC}_{50}$ of 0.0513 [24].

\section{Genotoxicity}

The effect of the of essential oil from $P$. corylifolia on DNA damage in individual cells of adult $C x$. quinquefasciatus was assessed by two distinct types of DNA damage measurements: the length of DNA comet tail and the percentage of fragmented DNA present in the tail after electrophoresis. The DNA damage was deduced in adult $C x$. quinquefasciatus when exposed to $0.034 \mathrm{mg} /$ $\mathrm{cm}^{2}$ and $0.069 \mathrm{mg} / \mathrm{cm}^{2}$ concentrations of essential oil of $P$. corylifolia using the comet assay method. The observation showed that DNA damage was significant i.e. $6.713 \%$ and $8.864 \%$ at $0.034 \mathrm{mg} / \mathrm{cm}^{2}$ and $0.069 \mathrm{mg} / \mathrm{cm}^{2}$ concentrations of essential oil in comparison to controls

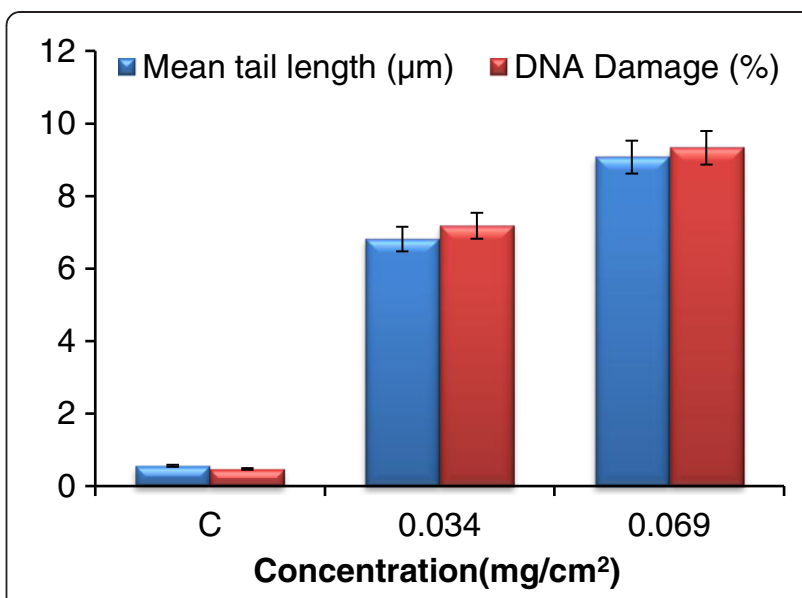

Figure 4 Effect of seed essential oil from $P$. corylifolia on tail length and DNA Damage against female Cx. Quinquefasciatus.

(Figure 4). The comet tail length increases with increase in concentration of essential oil of $P$. corylifolia, the tail length was $6.2548 \pm 0.754 \mu \mathrm{m}$ and $8.47 \pm 0.931 \mu \mathrm{m}$ at $0.034 \mathrm{mg} / \mathrm{cm}^{2}$ and $0.069 \mathrm{mg} / \mathrm{cm}^{2}$ concentration respectively with reference to control, which confirms the genotoxicity (Figure 4). A literature study revealed that there was DNA damage in mid gut cells of third instar larvae of $D$. melanogaster on exposure to chlorpyrifos for 24 and $48 \mathrm{~h}$, as assessed by comet assay. The tail length at $1.5 \mathrm{mg} / \mathrm{l}$ and $15.0 \mathrm{mg} / \mathrm{l}$ is $9.63 \mu \mathrm{m}$ and $19.26 \mu \mathrm{m}$ at $24 \mathrm{~h}, 9.87 \mu \mathrm{m}$ and $28.21 \mu \mathrm{m}$ at $48 \mathrm{~h}$, respectively. The DNA damage was $9.65 \%$ and $18.94 \%$ at $24 \mathrm{~h}, 1.09$ and $27.14 \%$ at $48 \mathrm{~h}$, respectively [64].

The possible mechanism of essential oil toxicity is either to react with DNA or by the generation of ROS (reactive oxygen species) therefore causing DNA damage including in the adult $C x$. quinquefasciatus. ROS are generated by inhibition of mitochondrial ATP synthesis through the uncoupling of oxidative phosphorylation that could lead to the generation of ROS $[64,65]$. During normal metabolism of the cell, ROS are generated in very low amounts and regulate various biological

Table 3 Mean knockdown time and corrected percent mortality of essential oil of $P$. corylifolia against adult $C x$. quinquefasciatus at different concentrations

\begin{tabular}{|c|c|c|c|c|}
\hline Concentration $\left(\mathrm{mg} / \mathrm{cm}^{2}\right)$ & $\% \mathrm{kd}$ in $1 \mathrm{hr}$. & $\mathrm{Kdt}_{50}$ & $\mathrm{Kdt}_{90}$ & $\%$ Corrected mortality in $24 \mathrm{hr}$. \\
\hline 0.034 & 38.3 & ND & ND & 20 \\
\hline 0.055 & 91.65 & $20.29 \pm 0.88$ & $47.87 \pm 3.18$ & 45 \\
\hline 0.069 & 100 & $18.06 \pm 1.32$ & $36.00 \pm 1.32$ & 70 \\
\hline 0.104 & 100 & $13.45 \pm 0.60$ & $25.75 \pm 1.25$ & 85 \\
\hline 0.138 & 100 & $11.16 \pm 0.49$ & $19.40 \pm 0.96$ & 95 \\
\hline 0.173 & 100 & $9.87 \pm 0.48$ & $17.85 \pm 0.95$ & 100 \\
\hline Control & 0 & - & - & 0 \\
\hline 0.05\% Deltamethrin & 100 & $14.91 \pm 0.67$ & $30.89 \pm 1.58$ & 96.7 \\
\hline
\end{tabular}

Kdt Knockdown time (minutes) \pm standard error, ${ }^{\mathrm{ND}}$ not determined. Six concentrations were tested with control (significantly different at $\mathrm{P}<0.05$ ) three replicates were taken. Kdt values were determined by probit analysis and mortality was corrected using Abbott's formula. 
processes such as signal transduction pathways. At high and/or sustained levels, they can cause severe damage to DNA, protein and lipids [66]. Various stressors present in the environment including pesticides are capable of reacting with DNA and causing DNA damage, stressors also have the capability to generate ROS, one of the possible mechanisms for the induction of DNA damage may be through the generation of ROS [67].

\section{Conclusion}

In the present study essential oil obtained from the seeds of $P$. corylifolia has shown potent toxicity against larvae and adults of Cx. quinquefasciatus. GC-MS analysis revealed the major constituents of essential oils were caryophyllene oxide, phenol,4-(3,7-dimethyl-3-ethenylocta-1,6-dienyl) and caryophyllene. The findings may be utilized for the development of eco-friendly insecticide, which could be used as an alternative for mosquito control.

\section{Competing interests}

The authors declare that they have no competing interest.

\section{Authors' contributions}

VKD designed the work and supervised the manuscript. AK performed experiments, interpretation of data and drafted the manuscript ACP performed entomological studies. SK Analysis of data and experimental work. All authors read and approved the final version of the manuscript.

\section{Acknowledgements}

We gratefully acknowledge the Integrated Diseases Vector Control (IDVC) program under the control of Indian Council of Medical Research, New Delhi for financial support to perform the study. We also acknowledge the NIMR Publication Committee to approve the contents of paper (No 014/2012).

\section{Author details}

${ }^{1}$ National Institute of Malaria Research, Sector-3, Health Centre, Field Unit BHEL, Ranipur, Hardwar, Uttrakhand 249403, India. ${ }^{2}$ Department of Biotechnology, Madhav Institute of Technology and Science, Gwalior 474005 (M.P), India.

Received: 31 August 2012 Accepted: 27 December 2012

Published: 4 February 2013

\section{References}

1. Korgaonkar NS, Kumar A, Dash A, Yadav RS, Kabadi D, Dash AP: Mosquito biting activity on humans \& detection of Plasmodium falciparum infection in Anopheles stephensi in Goa, India. Indian J Med Res 2012, 135:120-126.

2. Auguste AJ, Lemey P, Pybus OG, Suchard MA, Salas RA, Adesiyun AA, Barrett $A D$, Tesh RB, Weaver SC, Carrington CVF: Yellow fever virus maintenance in trinidad and its dispersal throughout the Americas. J Virol 2010, 84:9967-9977.

3. Githeko AK, Lindsay SW, Confalonieri UE, Patz JA: Climate change and vector-borne diseases: a regional analysis. Bull W H O 2000, 78:1136-1147.

4. Peng Z, Yang J, Wang H, Simons FER: Production and characterization of monoclonal antibodies to two new mosquito Aedes aegypti salivary proteins. Insect Biochem Mol Biol 1999, 29:909-914.

5. World malaria report 2011. Switzerland: WHO; 2011.

6. Fox LM: Infectious Diseases Related To Travel. In CDC Health Information for International Travel 2012. Edited by Brunette GW. New York: Oxford University Press; 2011.

7. Solomon T: Control of japanese encephalitis - within Our grasp? N Engl J Med 2006, 355:869-871

8. Global burden of dengue, Dengue and severe dengue WHO; 2012.

9. Populations at risk. Yellow fever: WHO; 2011.
10. Paily KP, Hoti SL, Balaraman K: Development of lymphatic filarial parasite wuchereria bancrofti (spirurida: onchocercidae) in mosquito species (diptera: culicidae) Fed artificially on microfilaremic blood. J Med Entomol 2006, 43:1222-1226.

11. Agrawal VK, Sashindran VK: Lymphatic filariasis in india problems, challenges and new initiatives. Med J Armed Forces India 2006, 62:359-362.

12. Webb JLA: The first large-scale Use of synthetic insecticide for malaria control in tropical Africa: lessons from Liberia, 1945-1962. J Hist Mede All Sci 2011, 66:347-376.

13. Fradin MS: Mosquitoes and mosquito repellents: a Clinician's guide. Ann Intern Med 1998, 128:931-940.

14. Aktar M, Paramasivam M, Sengupta D, Purkait S, Ganguly M, Banerjee S: Impact assessment of pesticide residues in fish of Ganga river around Kolkata in West Bengal. Environ Monit and Assesst 2009, 157:97-104.

15. Brausch JM, Smith PN: Pesticide resistance from historical agricultural chemical exposure in Thamnocephalus platyurus (Crustacea: Anostraca). Environ Pollut 2009, 157:481-487.

16. Thakur JS, Prinja S, Singh D, Rajwanshi A, Prasad R, Parwana HK, Kumar R: Adverse reproductive and child health outcomes among people living near highly toxic waste water drains in Punjab, India. J Epidemiol Community Health 2010, 64:148-154.

17. Cheng S-S, Chang H-T, Chang S-T, Tsai K-H, Chen W-J: Bioactivity of selected plant essential oils against the yellow fever mosquito Aedes aegypti larvae. Bioresource Technol 2003, 89:99-102.

18. Zhu J, Zeng X, Liu T, Qian K, Han Y, Xue S, Tucker B, Schultz G, Coats J, Rowley W, Zhang A: Adult repellency and larvicidal activity of five plant essential oils against mosquitoes. J Am Mos Control Assoc 2006, 22:515-522.

19. Cheng S-S, Liu J-Y, Tsai K-H, Chen W-J, Chang S-T: Chemical composition and mosquito larvicidal activity of essential oils from leaves of different cinnamomum osmophloeum provenances. J Agric Food Chem 2004, 52:4395-4400.

20. Cheng S-S, Liu J-Y, Huang C-G, Hsui Y-R, Chen W-J, Chang S-T: Insecticidal activities of leaf essential oils from Cinnamomum osmophloeum against three mosquito species. Bioresource Technol 2009, 100:457-464.

21. Cheng S-S, Chua M-T, Chang E-H, Huang C-G, Chen W-J, Chang S-T: Variations in insecticidal activity and chemical compositions of leaf essential oils from Cryptomeria japonica at different ages. Bioresource Technol 2009, 100:465-470.

22. Dua VK, Pandey AC, Dash AP: Adulticidal activity of essential oil of Lantana camara leaves against mosquitoes. Indian J Med Res 2010, 131:434-439.

23. Jantan I, Yalvema MF, Ahmad NW, Jamal JA: Insecticidal activities of the leaf oils of eight cinnamomum. Species against aedes aegypti and aedes albopictus. Pharm Biol 2005, 43:526-532.

24. Yang $P, M a Y$, Zheng S: Adulticidal activity of five essential oils against Culex pipiens quinquefasciatus. Pestic Sci Soc Japan 2005, 30:6.

25. Cilek JE, Hallmon CF, Johnson R: Efficacy of several commercially formulated essential oils against caged female aedes albopictus and culex quinquefasciatus when operationally applied via an automatictimed insecticide application system. J Am Mos Control Assoc 2011, 27:252-255.

26. Kalaivani K, Senthil-Nathan S, Murugesan A: Biological activity of selected Lamiaceae and Zingiberaceae plant essential oils against the dengue vector Aedes aegypti L. (Diptera: Culicidae). Parasitol Res 2012, 110:1261-1268.

27. Joshi SG: Medicinal Plants. New Delhi India: Oxford and IBH Publishing Co. Pvt. Ltd; 2000:206-207.

28. Panda H: In Herbs Cultivation and Medicinal Uses. New Delhi: National Institute Of Industrial Research; 2000:479-481.

29. Uikey SK, Yadav AS, Sharma AK, Rai AK, Raghuwanshi DK, Badkhane Y: The botany, chemistry, pharmacological and therapeutic application of psoralea corylifolia L. - A review. Int J Phytomedicine 2011, 2:100-107.

30. Khan MS, Siddiqui M, Aleem S: Effect of Psoralea corylifolia Linn. and Marham-e-Gulabi in Da-al-sadaf (psoriasis). Indian J Traditional Knowledge 2009, 8:425-430

31. Sah P, Agarwal D, Garg S: Isolation and identification of furocoumarins from the seeds of Psoralea corylifolia linn. Indian J Pharm Sci 2006, 68:768-771.

32. Qiao C-F, Han Q-B, Song J-Z, Mo S-F, Kong L-D, Kung H-F, Xu H-X: Chemical fingerprint and quantitative analysis of Fructus Psoraleae by highperformance liquid chromatography. J Sep Sci 2007, 30:813-818.

33. Ruan B, Kong LY, Takaya Y, Niwa M: Studies on the chemical constituents of Psoralea corylifolia L. J Asian Nat Prod Res 2007, 9:41-44. 
34. Latha PG, Evans DA, Panikkar KR, Jayavardhanan KK: Immunomodulatory and antitumour properties of Psoralea corylifolia seeds. Fitoterapia 2000, 71:223-231.

35. Matsuda H, Sugimoto S, Morikawa T, Matsuhira K, Mizuguchi E, Nakamura S, Yoshikawa M: Bioactive Constituents from Chinese Natural Medicines. XX. Inhibitors of Antigen-Induced Degranulation in RBL-2H3 Cells from the Seeds of Psoralea corylifolia. Chem Pharm Bull 2007, 55:106-110.

36. Shinde AN, Malpathak N, Fulzele DP: Determination of isoflavone content and antioxidant activity in Psoralea corylifolia L. callus cultures. Food Chem 2010, 118:128-132.

37. Khatune NA, Islam ME, Rahman MAA, Baki MA, Sadik G, Haque ME: Pesticidal Activity of a Novel Coumestan Derivative Isolated from Psoralea corylifolia Linn. Against Tribolium casteneum Herbst. Adults and Larvae (Coleptera:Tenebrionidae). J Agron 2002, 1:112-115.

38. Zaidi SFH, Yamada K, Kadowaki M, Usmanghani K, Sugiyama T: Bactericida activity of medicinal plants, employed for the treatment of gastrointestinal ailments, against Helicobacter pylori. J Ethnopharmacol 2009, 121:286-291.

39. Zhao L, Huang C, Shan Z, Xiang B, Mei L: Fingerprint analysis of Psoralea corylifolia L. by HPLC and LC-MS. J Chromatogr B 2005, 821:67-74.

40. Yi L-T, Li Y-C, Pan Y, Li J-M, Xu Q, Mo S-F, Qiao C-F, Jiang F-X, Xu H-X, Lu $X-B$, et al: Antidepressant-like effects of psoralidin isolated from the seeds of Psoralea Corylifolia in the forced swimming test in mice. Prog Neuropsychopharmacol Biol Psychiatry 2008, 32:510-519.

41. Cavallo D, Tomao P, Marinaccio A, Perniconi B, Setini A, Palmi S, lavicoli S: Evaluation of DNA damage in flight personnel by comet assay. Mutat Res Genetic Toxicol Environ Mutagen 2002, 516:148-152.

42. Godard T, Fessard V, Huet S, Mourot A, Deslandes E, Pottier D, Hyrien O, Sichel F, Gauduchon P, Poul J-M: Comparative in vitro and in vivo assessment of genotoxic effects of etoposide and chlorothalonil by the comet assay. Mutat Res Genetic Toxicol Environ Mutagen 1999, 444:103-116.

43. Valverde M, Rojas E: Environmental and occupational biomonitoring using the Comet assay. Mutat Res-Rev Mutat Res 2009, 681:93-109.

44. Dusinska M, Collins AR: The comet assay in human biomonitoring gene-environment interactions. Mutagenesis 2008, 23:191-205.

45. Committee on Mutagenicity of Chemicals in Food, Consumer Products and the Environment: [http://www.iacom.org.uk/index.htm].

46. NIST/EPA/NIH Mass spectral library. Gaithersburg, Maryland: National Institute of Standards and Technology; 1998.

47. Adams RP: Identification of essential oil components by gas chromatography/ mass spectroscopy. Carol Stream, Illinois: Allured Publishing Corporation; 2004.

48. World Health Organization: Guidelines For Laboratory and field Testing Of Mosquito Larvicides: WHO/CDS/WHOPES/GCDPP/ 2005:13.

49. World Health Organization: Instructions for determining the susceptibility or resistance of adult mosquitoes to organochlorine, organophosphate and carbamate insecticides: diagnostic test. Geneva: WHONBC/81.807; 1981.

50. Dua VK, Alam MF, Pandey AC, Rai S, Chopra AK, Kaul VK, Dash AP. Insecticidal Activity of Valeriana Jatamansi (Valerianaceae) Against Mosquitoes. J Am Mos Control Assoc 2008, 24:315-318.

51. Singh NP, McCoy MT, Tice RR, Schneider EL: A simple technique for quantitation of low levels of DNA damage in individual cells. Exp Cell Res 1988, 175:184-191.

52. Finney DJ: Probit Analysis By D J Finney, Volume 60. 3rd edition. 32 E. 57th St. New York: Cambridge University Press; 1971.

53. Abbott WS: A method of computing the effectiveness of an insecticide. 1925. J Am Mos Control Assoc 1987, 3:302-303.

54. Kapoor LD: Handbook of Ayurvedic Medicinal Plants. In Edited by Raton B. Florida: CRC Press; 2001:274-275.

55. Sharma PC, Yelne MB, Dennis TJ: Database on Medicinal Plants Used in Ayurveda. 2nd edition. New Delhi: Central Council for Research in Ayurveda and Siddha; 2001:89-93.

56. Liu ZL, Liu QR, Chu SS, Jiang GH: Insecticidal Activity and Chemical Composition of the Essential Oils of Artemisia lavandulaefolia and Artemisia sieversiana from China. Chem Biodivers 2010, 7:2040-2045.

57. Silva WJ, Dória GAA, Maia RT, Nunes RS, Carvalho GA, Blank AF, Alves PB, Marçal RM, Cavalcanti SCH: Effects of essential oils on Aedes aegypti larvae: Alternatives to environmentally safe insecticides. Bioresource Technol 2008, 99:3251-3255.

58. de Morais SM, Facundo VA, Bertini LM, Cavalcanti ESB, Anjos Júnior JF, Ferreira SA, de Brito ES, de Souza Neto MA: Chemical composition and larvicidal activity of essential oils from Piper species. Biochem Syst Ecol 2007, 35:670-675.

59. Koliopoulos G, Pitarokili D, Kioulos E, Michaelakis A, Tzakou O: Chemical composition and larvicidal evaluation of Mentha, Salvia and Melissa essential oils against the West Nile virus mosquito Culex pipiens. Parasitol Res 2010, 107:327-335.

60. Pavela R: Larvicidal property of essential oils against Culex quinquefasciatus Say (Diptera: Culicidae). Ind Crop Prod 2009, 30:311-315.

61. Ansari MA, Vasudevan P, Tandon M, Razdan RK: Larvicidal and mosquito repellent action of peppermint (Mentha piperita) oil. Bioresource Technol 2000, 71:267-271.

62. Dharmagadda VSS, Naik SN, Mittal PK, Vasudevan P: Larvicidal activity of Tagetes patula essential oil against three mosquito species. Bioresource Technol 2005, 96:1235-1240.

63. Liu Z, He Q, Chu S, Wang C, Du S, Deng Z: Essential oil composition and larvicidal activity of Saussurea lappa roots against the mosquito Aedes albopictus (Diptera: Culicidae). Parasitol Res, 1-6.

64. Gupta SC, Mishra M, Sharma A, Deepak Balaji TGR, Kumar R, Mishra RK, Chowdhuri DK: Chlorpyrifos induces apoptosis and DNA damage in Drosophila through generation of reactive oxygen species. Ecotox Environ Safe 2010, 73:1415-1423.

65. Ishii N, Senoo-Matsuda N, Miyake K, Yasuda K, Ishii T, Hartman PS, Furukawa S: Coenzyme Q10 can prolong C. elegans lifespan by lowering oxidative stress. Mech Ageing Dev 2004, 125:41-46.

66. Lau ATY, Wang Y, Chiu J-F: Reactive oxygen species: Current knowledge and applications in cancer research and therapeutic. J Cell Biochemy 2008, 104:657-667.

67. Wilson DM, Sofinowski TM, McNeill DR: Repair mechanisms for oxidative DNA damage. Front Biosci: a journal and virtual library 2003, 8:963-981.

doi:10.1186/1756-3305-6-30

Cite this article as: Dua et al:: Insecticidal and genotoxic activity of Psoralea corylifolia Linn. (Fabaceae) against Culex quinquefasciatus Say, 1823. Parasites \& Vectors $20136: 30$.

\section{Submit your next manuscript to BioMed Central and take full advantage of:}

- Convenient online submission

- Thorough peer review

- No space constraints or color figure charges

- Immediate publication on acceptance

- Inclusion in PubMed, CAS, Scopus and Google Scholar

- Research which is freely available for redistribution 